\title{
К истории вопроса о государственной принадлежности Крыма
}

Кремнев П.П.*

Историко-правовые вопросы о государственной принадлежности Крыма и г. Севастополя, имевшие особенно острый и дискуссионный характер в 90-е годы прошлого столетия, уже нашли свое отражение при обсуждении и принятии актов российским парламентом, в публикациях правоведов, историков, государственных и обшественных деятелей ${ }^{1}$. Считается общепризнанным, что передача Крымской области в состав Украинской ССР в 1954 г. партийно-государственным руководством страны была осуществлена в нарушение союзно-республиканского законодательства $\mathrm{CCCP}^{2}$, а юридически бесспорные права на Крым Украина приобрела со вступлением в силу «большого российско-украинского договора» 1997 г. Вместе с тем в свое время не получили должного историко-правового анализа и требующие разрешения следующие вопросы: о якобы существуюшей возможности возвращения Крыма под суверенитет Турции, правовом статусе Севастополя и полноценности самого Договора между Российской Федерацией и Украиной 1997 г. Эти проблемы и являются предметом настоящего исследования.

$\S 1$. В общественно-политических и научных кругах России в 19981999 годах развернулась широкая дискуссия, связанная с ратификацией российским парламентом Договора о дружбе, сотрудничестве и парт-

\footnotetext{
"Кремнев Петр Петрович - доцент кафедры международного права МГУ.

' Ведомости Съезда народных депутатов и Верховного Совета Российской Федерации. 1992. № 22. Ст. 1178; Бюллетень Государственной Думы. 1998. № 227; Бюллетень Совета Федерации. 1999. № 1; Бабурин С.Н. Территория государства. М., 1997; Московский журнал международного права. 1997. № 1; Россия, Крым и город русской славы Севастополь. Документы и материалы. 1783-1996. М., 1996; Обман века. Документы и материалы. М., 1999; Независимая газета: 1998, 25 марта; 1999, 26 января, 16 марта и др.

${ }^{2}$ Здесь уместно было бы напомнить слова профессора Университета св. Владимира (Киевского университета) В.А. Незабитовского, впервые обосновавшего концепцию территории как империума: «Государство владычествует в пределах территории, но не над территорией... Территория не вещь, которою владеет государство, но пространство, в пределах которого державная власть государства существует и действует) // Незабитовский В.А. Учение публицистов о межгосударственном владения. Киев, 1884. С. 140.
} 
нерстве между Российской Федерацией и Украиной от 31 мая 1997 г. В ходе этой дискуссии ряд известных представителей Государственной Думы и Совета Федерации Российской Федерации заявляли примерно следующее: «В русско-турецком договоре 1774 г. прямо говорится, что в случае выхода Крыма из состава российской территории Турция вправе восстановить над полуостровом свой суверенитет». Некоторые авторы высказывались и более категорично: «И действительно, согласно Кючук-Кайнарджийскому мирному договору 1774 года, в случае отказа России от Крыма суверенитет над Крымом автоматически передается Турции. Турция намерена добиваться возвращения Крыма через международные суды $)^{3}$. При этом в некоторых отечественных изданиях также указывалось, что и со стороны высокопоставленных турецких представителей в неофициальном порядке якобы высказывались похожие суждения ${ }^{4}$. Итак, существуют ли исторические правовые основания для подобных взглядов и имеет ли в настоящее время Турция какие-либо права на Крым согласно международному праву?

В результате успешной военной кампании 15 июля 1774 года $^{5}$ между Россией и Турцией был подписан договор - «Пункты вечного примирения и покоя между империями Всероссийскою и Портою Оттоманскою, заключенные в лагере при деревне Кючук-Кайнардже в четырех часах от города Силистрии» ${ }^{6}$ (известен как Кючук-Кайнарджийский мирный договор 1774 г.). Данное соглашение, состоящее из 28 артикулов (статей) и секретного приложения к нему (двух артикулов), было заключено на русском, турецком и итальянском языках; подлинный текст на русском языке и ратификационная грамота турецкого султана хранятся в Архиве внешней политики Российской Империи ${ }^{7}$. Текст этого договора под несколько измененным названием

${ }^{3}$ Федоров А.В. Правовой статус Крыма. Правовой статус Севастополя. М., 1999. С. 45. ${ }^{4}$ Там же; также см.: Старченков Г. Превратности судьбы // Азия и Афрнка сегодня. 1997. № 10. С. 9.

${ }^{5}$ Согласно артикулу 28 Трактата (второй абзац), полномочия на подписание договора от российской императрицы имел граф П. Румянцев, а от турецкого султана - верховный визирь Мегмет-паша, которые подписали и скрепили этот трактат свокми печатями 15 июля, что и должно считаться датой его подписания. 10 июля Трактат был скреплен подписями уполномоченных (от П. Румянцева - князь Н. Репнин) на разработку и согласование его текста, что ныне приравнивается $\mathbf{K}$ парафированию соглашения.

${ }^{6}$ Российский государственный военно-исторический архив. Ф. 846. ОП. 16. Д. 133. Л. 1-33.

'Архив внешней политики Российской Империи. Ф. 163 («Трактаты»). Оп. 2. Д. 445. 
(«Трактат вечного мира и дружбы, заключенный между Империю Всероссийскою и Оттоманскою Портою...») практически полностью был официально опубликован в России, за исключением двух секретных артикулов ${ }^{8}$. Ключевым положением договора является артикул третий, согласно которому Крымское ханство получало независимость: «Все татарские народы: крымские, буджаитские, кубанские... без изъятия от обеих империй имеют быть признаны вольными и совершенно независимыми от всякой посторонней власти, но пребывающими под самодержавною властию собственного их хана Чингисского поколения... ни Российский двор, ни Оттоманская Порта не имеют вступаться как в избрание и возведение помянутого хана, так и в домашние, политические, гражданские и внутренние их дела ни под каким видом...». В некоторое заблуждение (которое не возникнет, если внимательно ознакомиться с текстом всего договора) может ввести положение этого же третьего артикула: «В духовных же обрядах, как единоверные с мусульманами, в рассуждении его султанского величества, яко верховного халифа магометанского закона, имеют сообразоваться правилам, законом их предписанным, [sic!] без малейшего предосуждения однако ж утверждаемой для них политической и гражданской вольности». В сепаратных артикулах допускался более поздний срок (а не в течение предусмотренных трех месяцев) освобождения русским флотом занятых островов (артикул первый), а для Оттоманской Порты устанавливалась военная контрибуция в пользу Российской Империи (артикул второй).

Известие о подписании Турцией договора об утрате Крымского ханства произвело в Европе настоящую сенсацию ${ }^{10}$ и вызвало возмущение против Порты. Венский двор заявлял: «Турки вполне заслужили несчастие, которое их постигло, частию своим слабым и глупым ведением войны, частию недостатком доверия к державам, которые [Австрия, Англия, Голландия] ...желали высвободить их из затруднительного положения ....и помогли бы им получить выгоднейшие условия»". В этой обстановке турецкий Диван (правительство) пытался потребо-

\footnotetext{
${ }^{8}$ Полное собрание законов Российской Империи. Т. ХІХ. № 14164. С. 957-967.

9 «Пятнадцать тысяч мешков, которые учинят семь миллионов пятьсот тысяч пиастров, а на российскую монету сделают сумму четыре миллиона пятьсот тысяч рублей», выплачиваемых в течение трех лет тремя равными траншами.

${ }^{10}$ «Невероятно, - сообщал российский посол во Франции И. Барятинский, - до какой степени простирается здесь зависть к нашим успехам» // Соловьев С.М. История России с древнейших времен. Книга шестая. Т. XXIX. Санкт-Петербург, 1895. С. 999.
} 
вать изменения условий Трактата 1774 г., на что Екатерина II в специальном рескрипте графу П. Румянцеву-Задунайскому (подписавшему трактат со стороны Российской Империи) указывала: «Ни малейшая перемена в тексте трактата Порте от нас дозволена быть не может» ${ }^{12}$. Фельдмаршал П. Румянцев даже дал секретное поручение русскому посланнику в Константинополе Петерсону обещать «100, 200, наконец 300 тыс. рублей тому, кто возьмется уничтожить все происки недоброжелательных людей» и эффективно способствовать ${ }^{13}$ ратификации Турцией трактата без каких-либо изменений ${ }^{14}$. Трактат в неизменном виде был ратифицирован турецким султаном и 13 января 1775 г. в Константинополе произошел обмен ратификационными грамотами ${ }^{15}$. Характерно, что в России не находили связи между «духовным сопряжением магометанской веры», «всеми магометанами признаваемого халифства в особе султана турецкого» и получаемой Крымским ханством политической независимостью. Вмешательство же русского двора в эти духовные связи «...знаменовало бы пред светом больше самой Порты подчинение России, нежели какову она сама ищет над татарами в пункте сего сопряжения. Удивительно, что турецкие министры не ощутят сего осязательного неудобства, в котором бы конечно преемники их за них стыдиться стали», - отмечала в свое время российская императрица ${ }^{16}$. Положения Трактата 1774 г. и независимость Крымского ханства подтверждались Российской Империей и Оттоманской Портой в Изъяснительной конвенции 1779 r. ${ }^{17}$ (известна также как Айналы-Кавакская конвенция), Акте 1783 г. «О мире, торговле и границах обеих государств» ${ }^{18}$ (Трактат торговли 1783 г.). В связи с серьезными нарушениями Турцией условий Трактата 1774 г. по Указу Екатерины II от 7 сентября 1787 г. Крым был присоединен к территории России и вошел в состав Таврической губернии ${ }^{19}$. Такой статус Крыма был вскоре признан Турцией в Ясском договоре.

${ }^{11}$ Там же. С. 998.

${ }^{12}$ Дубровин Н. Присоединение Крыма к Россин. Т. І. Санкт-Петербург, 1885. С. 1.

${ }^{13}$ Два влиятельных фаворита султана получили от Петерсона по 6\% от военной контрибуции Порты // Дружинина Е.И. Кючук-Кайнарджийский мир. М., 1955. С. 312 317.

${ }^{14}$ Соловьев С.М. Указ. соч. С. 983.

${ }^{15}$ Полное собрание законов Российской Империи. Т. ХХ. № 14274. С. 81.

${ }^{16}$ Дубровин Н. Указ. соч. С. 2.

${ }^{17}$ Полное собрание законов Российской Империи. Т. ХХ. № 14851. С. 800-805.

${ }^{18}$ Там же, Т. XXI. № 1591. C. 1082-1083.

${ }^{19}$ Российский государственный военно-исторический архив. Ф. 846. Оп. 16. Д. 133. Л. 10-12. 
Итак, ничто в соответствующих российско-турецких договорах не дает основания считать, что Крым мог находиться под суверенитетом «третьей стороны». В качестве исторической аналогии можно отметить, что в Договоре между Россией и Турцией от 16 марта 1921 г. стороны были согласны с образованием Нахичеванской области как автономной территории «под протекторатом Азербайджана, при условии, что Азербайджан не уступит сего протектората третьему Государству» (cт. III) $^{20}$. Но даже если бы подобное положение в отношении Крымского ханства и было закреплено в трактате 1774 г., то на основании принципов правопреемства права на Крым переходили бы к Украине, т.к. она в XVIII веке находилась в составе Российской Империи и не может считаться третьей стороной.

$\S 2$. В отечественной правовой науке и общественном мнении в отношении Севастополя существовали примерно следующие устойчивые взгляды: Указом Президиума Верховного Совета РСФСР 1948 г. Севастополю был придан статус города республиканского подчинения, и как самостоятельный административно-хозяйственный центр он был выведен из состава Крымской области. В актах 1954 г. о передаче Крыма Укранне Севастополь не упоминается. И поскольку впоследствии Указ 1948 г. никогда не отменялся и «юридически сохраняет свое значение до настоящего времени), вплоть до распада СССР Севастополь оставался городом союзно-республиканского значения, а Россия «как продолжатель территориальных прав РСФСР вправе осуществлять свой суверенитет в отношении Севастополя», в том числе на основании международно-правового обычая ${ }^{21}$. Автор настоящей публикации и сам был склонен к подобной точке зрения, однако более глубокое изучение данного вопроса (патриотизм не всегда тождественен научно-правовому анализу) приводит к другим выводам.

Согласно действовавшему государственно-территориальному устройству по республиканской Конституции 1937 г. «РСФСР состоит из

${ }^{20}$ Документы внешней политики СССР. Т. III. М., 1959. С. 310. Характерно, что в соответствии с положениями Карского договора от 13 октября 1921 г. правительства Турции, Азербайджана и Армении устанавливали нахождение автономной территории Нахичеванской области «под покровительством Азербайджана) (ст. 5), норма о запрещении перехода такого покровительства от Азербайджана третьей стороне отсутствовала (Там же. С. 317).

${ }^{21}$ Блищенко И.П., Лейбо Ю.И., Молодцов С.В. Топорнин Б.Н. См.: Россия, Крым и город русской славы Севастополь. Документы и материалы. 1783-1996. М., 1996. С. 105111; Федоров А.В. Указ. соч. С. 32-35. 
краев, областей, автономных республик и автономных областей» (ст. 14), такой же принцип устанавливался и в Конституции СССР 1936 г. (ст. 22). Города республиканского подчинения (порядок назначения, утверждение союзными органами), а тем более их самостоятельный государственно-территориальный статус союзно-республиканским конституционным законодательством не предусматривались, равно как и городов краевого и областного подчинения (например, Барнаул, Новороссийск, г. Рассказово Тамбовской области, г. Камышин Сталинградской области ${ }^{22}$ ). Такие города устанавливались указами Президиумов Верховных Советов союзных республик (Ташкент, г. Рустави Грузинской $\mathrm{CCP}^{23}$ ), которые, естественно, не могли изменять действовавшее конституционное законодательство.

Согласно Указу Президиума Верховного Совета РСФСР от 29 октября 1948 г., «город Севастополь выделен в самостоятельный административно-хозяйственный центр со свонм особым бюджетом и отнесен к категории городов республиканского подчинения» ${ }^{24}$. Неверно считать, что такое выделение Севастополя «резко отличало его статус по сравнению с другими городами... всего СССР»; «этот статус присваивался в сталинскую эпоху крайне редко» ${ }^{25}$, и такими городами являлись лишь Москва, Ленинград, Ташкент и Минск. Только в России на основании Указов Президиума Верховного Совета РСФСР ${ }^{26}$ такой статус был придан 15 городам (Горький, Куйбышев, Омск, Ростовна-Дону, Саратов, Свердловск, Сочи, Новосибирск и др. ${ }^{27}$ ). Являясь «административно-хозяйственными центрами республиканского подчинения», они обладали отдельным (от края/области) бюджетом и финансированием, в административном подчинении городские законодательные и исполнительные органы напрямую (минуя краевые/областные инстанции) замыкались на соответствующие республиканские органы власти. Эти города в самостоятельную государственно-территориальную единицу не выделялись (например, Сочи из Краснодарс-

\footnotetext{
${ }_{22}^{21}$ Ведомости Верховного Совета СССР. 1943, 23 апреля, 4 и 11 мая.

${ }^{23}$ Указы Президиумов Верх. Сов. Узбекской ССР от 12.10.1943 г., Грузинской ССР от 19.01.1948 r.

${ }^{24}$ Ведомости Верховного Совета СССР. 1948, 10 декабря.

${ }^{25}$ Похлебкин В.В. К истории административно-правового и государственного статуса города, порта и военно-морской базы Севастополя (1783-1996) // Московский журнал международного права. 1997. № 1. С. 111, 117.

${ }^{26}$ Ведомости Верховного Совета СССР. 1943, 17 июня, 30 июля, 24 декабря и др.

${ }^{27}$ РСФСР. Административно-территориальное деление. М., 1955. С. IV-VII.
} 
кого края, Ленинград из Ленинградской области), а продолжали оставаться в составе соответствуюшей области или края.

При решении вопроса о государственной принадлежности какойлибо территории, в случае отсутствия ее международно-договорного закрепления между спорящими сторонами, решающее значение имеет факт распространения на эту территорию чьих-либо суверенных полномочий. В частности, какая из сторон осуществляла над ней законодательную, исполнительную и судебную юрисдикцию (при условии, если осуществление таких действий не противоречит общему международному праву, т.е. не является следствием неправомерной оккупации, аннексии и т.п.). Такой подход соответствует доктрине международного права и практике Международного Суда ООН. Согласно Указу Президиума Верховного Совета РСФСР, на 1 марта 1959 г. назначались выборы в Верховный Совет республики и Советы окружных, городских и районных депутатов трудящихся ${ }^{28}$ (т.е. законодательные органы), первые после передачи Крыма в 1954 г. По этим выборам избирательного округа по Севастополю образовано не было ${ }^{29}$, соответственно отсутствуют и избранные в высший орган власти РСФСР и депутаты от Севастополя ${ }^{30}$. Из этого следует, что законодательная власть РСФСР на Севастополь уже не распространялась.

С января 1955 г. среди городов республиканского (РСФСР) подчинения Севастополь уже не значился ${ }^{31}$, исполнительную юрисдикцию над ним РСФСР с того времени не осуществляла. Также нет доказательств тому, что выносимые Севастопольским городским судом решения основывались на уголовном, гражданском, семейном и трудовом законодательстве РСФСР. Следовательно, после 1954 г. Севастополь, как составная часть Крымской области, находился под юрисдикцией Украинской ССР. Конечно, в истории России Севастополь как город русской славы занимает особое место. В качестве крупнейшей военно-морской базы страны город имел общесоюзное значение, его финансирование осуществлялось за счет средств союзного, а не республиканского (украинского) бюджета. Но с формально-правовой точки зрения, а именно с позиций союзно-республиканского конституционного законодательства, Севастополь являлся частью терри-

\footnotetext{
${ }^{28}$ Советская Россия. 1959, 4 января.

${ }^{29}$ Советская Россия. 1959, 7 и 8 января.

${ }^{30}$ Советская Россия. 1959, 6 марта.

${ }^{31}$ РСФСР. Административно-территориальное деление. М., 1955. С. IV-VII.
} 
тории Крымской области. Поэтому проблема его правового статуса должна решаться в контексте постановки вопроса о Крыме в целом. Иной подход, т.е. наделение Севастополя статусом самостоятельной территориальной единицы, представляется юридически необоснованным и способен лишь увести разговор от сушества вопроса в ошибочном направлении.

$\S 3.1$ апреля 1999 г. вступил в силу Договор о дружбе, сотрудничестве и партнерстве между Российской Федерацией и Украиной (далее Договор), подписанный 31 мая 1997 г. президентами России и Украины. Затянувшийся перерыв между подписанием и вступлением Договора в силу явился следствием острых дискуссий в обеих палатах Федерального Собрания Российской Федерации по ключевому территориальному вопросу - о государственной принадлежности Крыма в целом и Севастополя в частности. Поскольку в договоре между РСФСР и Украинской ССР от 19 ноября 1990 г. признавалась территориальная целостность сторон «в ныне существующих в рамках СССР границах», подлежащих регулированию внутригосударственным правом Союза ССР, то вопрос о государственной принадлежности Крыма с международно-правовых позиций до 1 апреля 1999 г. оставался неразрешенным. Договором 1997 г. устанавливалось, что «Высокие Договариваюшиеся Стороны в соответствии с положениями Устава ООН... уважают территориальную целостность друг друга и подтверждают нерушимость существующих между ними границ» (ст. 2). Таким образом, в случае правомерности заключения Договора Украина впервые получала полноценные права на Крым, а Россия утрачивала возможность предъявления на него юридически обоснованных претензий. Однако на завершающей стадии заключения данного соглашения (принятие парламентами актов о его ратификации) обеими сторонами были допушены сушественные нарушения, которые способны поставить под сомнение полноценность и действительность Договора.

В соответствии с Конституцией РФ (ст. 106) и Законом о международных договорах 1995 г. (ст. 14) ратификация Россией международных договоров осуществляется в форме федеральных законов. Подписание Президентом РФ 2 марта 1999 г. Федерального закона «О ратификации Договора» породило сложную юридическую ситуацию в отношении самого закона и, как следствие, в отношении Договора в целом. Основным (но не единственным) правовым изъяном Федерального закона «О ратификации Договора» является разная редакция 
или неидентичность принятого Государственной Думой и одобренного Советом Федерации текста закона ${ }^{32}$, что ставит под сомнение результаты волеизъявления законодателя и государственно-правовой доктриной толкуется как «порок воли законодателя». С позиций международно-правовой доктрины такая ситуация фактически означала замену ратификации обычной (безусловной) на ратификацию условную $^{33}$. По сушествующей в РФ законотворческой практике такие акты подлежат не подписанию Президентом, а возвращению в Федеральное Собрание для их принятия «в единой редакции» ${ }^{34}$. Таким образом были созданы основания для направления в Конституционный Суд правомерного и обоснованного запроса о соответствии Конституции РФ не Договора (согласно п. 2 ст. 125 Конституции Суд не вправе рассматривать вступившие в силу международные договоры), а самого Федерального закона «О ратификации Договора».

Конституционный порядок ратификации Договора был нарушен также и украинской стороной. Согласно Закону «О международных договорах Украины» 1993 г., ратификация международных соглашений Украины осуществляется в форме принятия Верховной Радой специального закона, который подписывается Председателем Рады (ч. 1 ст. 7). В соответствии с этим порядком 14 января 1998 г. Верховная Рада приняла, Председатель Рады тогда же подписал Закон «О ратификации договора о дружбе, сотрудничестве и партнерстве между Российской Федерацией и Украиной», и в таком виде он был официально опубликован. В таком же порядке (подписания и опубликования) Украина ратифицировала все международные договоры вплоть до середины 2000 г. Вместе с тем в Конституции Украины 1996 г. устанавливается, что принятые Верховной Радой и подписанные ее Председателем законы подлежат «безотлагательному направлению» Президенту для последующего подписания и «официального обнародования» (ст. 94). В этой связи оставался невыясненным вопрос - следует ли считать специальные законы о ратификации международных договоров отдельными от остальных законов Украины, подлежат ли они направлению на подпись президенту и каков порядок их опубликования? Эта колли-

\footnotetext{
${ }^{32}$ См.: Кремнев П.П. Некоторые правовые вопросы заключения Договора о дружбе, сотрудничестве и партнерстве между Российской Федерацией и Украиной // Вестник Московского университета. Серия 11. Право. 1999. № 4. С. 86-88.

${ }^{33}$ Там же. С. 87.

${ }^{34}$ См.: Постановление Конституционного Суда от 22.04.1996 г. // СЗ РФ. 1996. № 118. Ст. 2253.
} 
зия была разрешена Конституционным Судом Украины при рассмотрении поступившего от 54 депутатов Рады запроса о конституционности Закона «О ратификации Европейской хартии региональных языков и языков меньшинств 1992 г.», который был подписан Председателем Рады 29 декабря 1999 г. и официально опубликован на следующий день. Суд установил, что установленный в статье 94 Конституции Украины порядок (т.е. все принятые и подписанные Председателем Верховной Рады законы, в том числе о ратификации международных договоров, подлежат направлению президенту на подпись с последующим официальным обнародованием) был нарушен при принятии закона о ратификации Европейской хартии 1992 г. В своем решении от 12 июня 2000 г. Суд постановил, что положения ч. 1 ст. 7 Закона «О международных договорах Украины» не соответствуют Конституции Украины (п. 2), а сам Закон от 29 декабря 1999 г. о ратификации Европейской хартии признал неконституционным (п. 1) и утратившим силу со дня объявления данного решения (п. 3$)^{35}$.

Таким образом, какое же правовое положение сложилось в отношении российско-украинского договора 1997 г. с учетом изложенных факторов? И с российской, и с украинской стороны законы о его ратификации были приняты с нарушением установленного конституционного порядка. В связи с чем вполне возможно предположить, что в случае направления соответствующего запроса в Конституционный Суд Российской Федерации и особенно Украины (вынесение решения по аналогии) соответствующий суд мог признать закон о ратификации Договора не соответствующим Конституции. Как известно, процесс ратификации является завершающей стадией заключения международного договора. Такая ситуация означала бы отсутствие юридической силы договора внутри страны, в международно-правовом смысле договор продолжал бы оставаться действующим до тех пор, пока одна из сторон не оспорила бы его действительность. Согласно положениям ст. 46 (недействительность договора) Венской конвенции о праве международных договоров 1969 г, государство вправе ссылаться на недействительность согласия при заключении договора в случае явного нарушения «нормы его внутреннего права особо важного значения» (т.е. конституционного характера). Таким образом, действительность российско-украинского договора 1997 г. основывалась не на его полноценности и полноправности, а находилась в прямой зависимости

\footnotetext{
${ }^{35}$ Вісник Конституційного Суду Украіни. 2000. № 3. С. 5-9.
} 
от возможного признания его недействительным по инициативе любой из сторон (в журналистике такой договор называют «хромающий на обе ноги»). И такое международно-правовое положение вокруг Договора могло существовать вплоть до наступления действия принципа эстоппель: по прошествии какого-то периода времени (международным правом точно не определенного) государство «должно в силу его поведения считаться молчаливо согласившимся» с тем, что договор действителен или остается в действии (ст. 45 Конвенции 1969 г.).

Однако к настоящему времени изложенное относится к Договору 1997 г. в целом, но уже не затрагивает правового статуса Крыма. В соответствии с международно-правовой практикой территориальное разграничение между государствами устанавливается не рамочными или «большими» межтосударственными договорами, а отдельными соглашениями с описанием прохождения линии государственной границы и ее отображением на карте. Такое соглашение, Договор между Российской Федерацией и Украиной о российско-украинской государственной границе, было подписано 28 января 2003 г. в Киеве. Государственная Дума РФ приняла закон о его ратификации 20 апреля 2004 г., а уже 25 апреля состоялся обмен ратификационными грамотами и договор вступил в силу (ст. 6). Согласно смыслу положений Договора 2003 г. (преамбула, ст. 1) и линии прохождения российско-украинской государственной границы (ст. 2, Приложение 1 и 2) Крымский полуостров признается частью государственной территории Украины.

В свое время президент Украины Л. Кучма отмечал: «Есть конституция страны [Украины], есть так называемый «Большой договор» с Россией - и все, и точка. Разговор на эту тему возможен в приличном, так сказать, обществе только в одном случае, под одним соусом - в порядке анализа мифа об особых «исторических правах» России на Крым. Не опровергать миф, а исследовать его» ${ }^{36}$. С учетом международно-правового анализа (исследованием мифов занимаются в основном историки и филологи) можно согласиться с Л. Кучмой в том плане, что только после вступления в силу российско-украинского договора об установлении межгосударственных границ вопрос о юридической принадлежности Крыма России отошел к области преданий и приобрел исторический характер, а Украина с 25 апреля 2004 г. получила на эту территорию полноценные и уже неоспоримые юридические права с позиций международного и внутригосударственного права.

\footnotetext{
${ }^{36}$ Кучма Л.М. Украина - не Россия. М., 2003. С. 498.
} 